\title{
MEMPREDIKSI FAKTOR-FAKTOR YANG MEMPENGARUHI LOYALITAS KONSUMEN TERHADAP PEMBELIAN ONLINE: SUATU STUDI EMPIRIS
}

\author{
Jessica Suryadijaya ${ }^{1}$ \\ Fakultas Ekonomi dan Bisnis Universitas Pelita Harapan \\ jessicasuryadijaya@gmail.com \\ Natasya Metta Gunawan ${ }^{2}$ \\ Fakultas Ekonomi dan Bisnis Universitas Pelita Harapan \\ natasyametta@gmail.com \\ Sabrina O. Sihombing ${ }^{3}$ \\ Fakultas Ekonomi dan Bisnis Universitas Pelita Harapan \\ sabrina.sihombing@uph.edu \\ Diterima 5 Mei 2020 \\ Disetujui 23 Juni 2020
}

Abstract- This study aims to test consumer loyalty to GrabFood in terms of security, privacy, service fulfillment, non decptionand satisfaction from GrabFood consumers themselves. The sampling design used is purposive sampling which is a nonprobability sampling. All research indicators come from previous studies. Before testing hypotheses using structural equation modeling, the reliability and validity tests were carried out. The results of this study indicate that there is a significant relationship between security and non-deception on consumer satisfaction, and not deception and fulfillment of services to loyalty, both directly and indirectly. Based on the results of this study also, it was said that between customer satisfaction and customer loyalty, there was a significant relationship. This study suggests factors that must be considered by an online business in gaining customer loyalty.

Keywords: Consumer Satisfaction, Consumer Loyalty, Security, Fulfillment, Non Deception, Privacy 


\section{PENDAHULUAN}

Perkembangan teknologi informasi sangat pesat pada saat ini. Secara spesifik, teknologi memberikan perubahan yang signifikan terhadap ekonomi dan pola perilaku masyarakat dalam banyak hal seperti bekerja, berbelanja, berkomunikasi dan lainnya. Dengan smartphone dan internet, orang dapat mengakses informasi dan banyak hal lain dengan lebih mudah.

Salah satu perusahaan teknologi yang sedang booming adalah Grab. Dengan berbagai layanan yang diberikan, GrabFood menjadi salah satu layanan yang paling berpengaruh dalam perkembangan Grab itu sendiri. Grab merupakan sebuah perusahaan decacorn yang terbentuk pada tahun 2012 di Kuala Lumpur, Malaysia. Dimulai dari gudang kecil, Grab telah menjadi perusahaan teknologi berbasis internet terbesar di Asia Tenggara. Grab juga telah menghubungkan jutaan mitra pengemudi, merchant, dan bisnis untuk mengatasi berbagai masalah yang ada, seperti ketimpangan akses, ketertinggalan infrastruktur, dan kesenjangan pendapat (www.grab.com, 2020).

Grab memilih untuk berkembang di Asia Tenggara karena Asia Tenggara merupakan daerah dengan pertumbuhan ekonomi tercepat di dunia. Walaupun Asia Tenggara memiliki banyak hambatan infrastruktur, 73 persen masyarakatnya percaya bahwa mereka dapat mencapai mimpi terbesar mereka. Berdasarkan hasil riset yang dilakukan oleh Centre for Strategic and International Studies (CSIS) dan Tenggara Strategics, empat lini usaha Grab, yaitu GrabBike, GrabCar, GrabFood, dan Kudo, telah memberikan kontribusi sebesar Rp 48,9 triliun terhadap perekonomian Indonesia pada tahun 2018. Kontribusi terbesar yang diberikan Grab ialah melalui GrabFood yang diperkirakan mencapai Rp 20,8 triliun (Jati, 2019).

Grab bukanlah satu-satunya perusahaan teknologi penyedia jasa yang tenar di Indonesia. Sebelumnya, telah hadir perusahaan serupa hasil karya anak bangsa, yaitu GoJek. Dengan variasi layanan yang serupa, GoJek mempunyai layanan bernama GoFood yang merupakan jasa pengiriman makanan. Ketika disandingkan dengan GoFood, performa GrabFood di mata konsumen masih kalah. Walaupun kontribusi yang diberikan GrabFood cukup besar, cnnindonesia (2019) menyatakan bahwa GrabFood hanya menguasai 39,9 persen pangsa pasar. Riset oleh Alvara Strategic Research (2019) menunjukkan bahwa dari 1054 responden, sebesar 77,6 persen merupakan pengguna mobile application di Jakarta dan sebesar 80,5 persen merupakan pengguna yang tersebar di Bogor, Depok, Tangerang, dan Bekasi. Kemudian, data riset Alvara menggambarkan persentase perbandingan pengguna aplikasi jasa pengiriman makanan GrabFood dan GoFood. Pengguna layanan GrabFood hanya sebesar 39,9 persen jauh berada di bawah GoFood dengan persentase 71,7 persen. Hasil riset juga menunjukkan tingkat penggunaan brand GrabFood sebesar 39,9 persen jauh lebih kecil dibandingkan GoFood dengan persentase sebesar 71,7 persen. Padahal, GrabFood juga lebih diasosiasikan dengan harga yang murah dan banyak promo dibandingkan kualitas layanannya (www.cnnindonesia.com, 2020).

Berdasarkan fenomena tersebut, penelitian ini bertujuan untuk memeprediksi loyalitas dengan menggunakan model yang telah dikembangkan oleh Limbu et al. (2011). Model ini diuji kembali karena model ini mengintegrasikan variabel non deception (selanjutnya disebut bukan pengelabuan/penipuan). Salah satu masalah utama dalam promosi adalah berkaitan dengan nonpenipuan di mana para konsumen percaya bahwa penjual tidak menggunakan praktik menipu atau manipulatif dengan maksud untuk membujuk konsumen untuk membeli (Limbu et al., 2011). 


\section{TINJAUAN PUSTAKA}

Kepuasan konsumen adalah perasaan seseorang yang baik atau buruk setelah membandingkan produk berdasarkan apa yang dirasakannya dengan apa yang menjadi harapannya (Saleem et al., 2015). Karena loyalitas konsumen dianggap sebagai tujuan vital untuk kelangsungan hidup dan pertumbuhan perusahaan, membangun basis konsumen yang loyal tidak hanya menjadi tujuan pemasaran utama, tetapi juga merupakan sebuah dasar yang penting untuk meningkatkan keunggulan yang kita miliki secara berkelanjutan (Chung et al., 2015).

Dalam studinya pada tahun 2007, Roman mengembangkan suatu skala untuk menganalisa persepsi konsumen tentang etika pengecer online. Skala tersebut awalnya diimplementasikan dengan dua sampel kenyamanan konsumen online yang terpisah. Skala menunjukkan sifat psikometrik yang baik berdasarkan temuan dari berbagai uji reliabilitas dan validitas (Roman, 2010). Temuan ini menyimpulkan bahwa etika online yang dirasakan dapat dibagi menjadi empat faktor yaitu: keamanan, privasi, bukan pengelabuan, serta pemenuhan layanan, dan dugaan pelanggaran terhadap salah satu dari keempat faktor tersebut dapat menimbulkan masalah etika tentang pengecer online (Limbu et al., 2011). Faktor-faktor yang digunakan dalam penelitian ini serta hubungannya dengan variabel dependennya akan dijelaskan sebagai berikut.

Keamanan. Dalam sebuah layanan online, keamanan adalah hal yang sangat penting dan dibutuhkan oleh konsumen. Menurut Grandinetti (1996), keamanan didefinisikan sebagai perlindungan suatu data dari pihak-pihak yang tidak bertanggungjawab atau tidak berhak, sementara Casalo et al. (2007) mendefinisikan keamanan sebagai jaminan teknis bahwa praktik hukum dan etika terpenuhi (Chiu et al., 2017). Sebuah vendor online perlu untuk mencegah resiko dan meningkatkan keamanan dalam e-commerce, termasuk di dalamnya: penggunaan teknologi terkini, prosedur pembayaran yang jelas, pengamanan data dan pernyataan keamanan (Bashir, 2015).

Pemenuhan Layanan. Dalam penggunaan aplikasi untuk melakukan transaksi, tentunya akan ada banyak tantangan. Tantangan tersebut bisa saja dalam hal ketepatan dalam pemesanan dan pengantaran produk yang dipesan oleh konsumen maupun ketepatan dalam segi waktu pengantaran pesanan ke konsumen. Tantangan logistik ini merujuk pada pemenuhan back-end dan distribusi jarak tempuh terakhir dari suatu pesanan (Pan et al., 2017). Dalam penelitian ini, istilah fulfillment (pemenuhan) mengacu pada pengiriman pembelian online yang tepat waktu dan akurat, representasi produk, serta fungsi situs web yang tepat (Limbu et al., 2011).

Non Penipuan. Penipuan atau deception dapat didefinisikan sebagai menyembunyikan atau menyamarkan tujuan sebenarnya dari suatu percobaan untuk menghindari reaktivitas yang disadari dari para peserta yang akan membuat data ini tidak berharga (Krawczyk, 2019). Penipuan terjadi ketika seseorang secara sadar mentransmisikan sebuah pesan untuk menumbuhkan keyakinan yang salah atau kesimpulan yang salah oleh penerima (Triki, 2019). Dengan demikian, dalam penelitian ini, non deception (bukan penipuan/pengelabuan) mengacu pada keyakinan konsumen bahwa penyedia layanan elektronik tidak akan melakukan penipuan untuk mempengaruhi konsumen dalam melakukan transaksi pada suatu produk (Elbeltagi dan Agag, 2015).

Privasi. Konsep dari Internet of Things (IoT) sudah berkembang sejak munculnya koeksistensi dunia nyata dan dunia virtual, dengan prinsip utamanya yaitu membuat komputer memproses informasi tanpa bantuan dari manusia (Shenkoya dan Dae-Woo, 2019). GrabFood sendiri adalah salah satu bagian dari IoT yang memudahkan konsumen dalam menjangkau dan 
berhubungan dengan produsen (dalam GrabFood adalah restoran maupun penjual minuman maupun makanan yang bekerja sama dengan Grab) dengan bantuan aplikasi berbasis internet. Dengan berbasis internet menyebabkan munculnya rasa tidak aman dari konsumen. Tidak adanya perlindungan privasi telah terbukti menjadi salah satu faktor yang mempengaruhi penerimaan dan adopsi IoT (Padyab dan Ståhlbröst, 2018). Dalam penelitian ini, masalah privasi merujuk pada tingkat kecemasan konsumen tentang kemungkinan informasi pribadi, rahasia atau sensitif konsumen dapat dipantau, diekspos atau disalahgunakan oleh orang lain di luar maupun di dalam jaringan (Malik et al., 2020).

Kepuasan Konsumen. Kepuasan konsumen adalah kombinasi dari emosi dan respon konsumen (Nawi et al., 2019). Tse dan Wilton pada tahun 1988 menyatakan bahwa kepuasan konsumen pada umumnya terkait dengan respon emosional konsumen terhadap pengalaman atas suatu produk atau layanan setelah pembelian, serta hasil yang diharapkan dan dirasakan setelah pemakaian produk (Song et al., 2019). Kepuasan konsumen adalah penilaian terhadap fitur produk atau jasa, atau produk atau jasa itu sendiri, memberikan pemenuhan konsumsi yang menyenangkan atau kurang/terlalu berlebihan (Monferrer et al., 2019).

Loyalitas Konsumen. Loyalitas konsumen dapat didefinisikan dalam hal perilaku pembelian berulang atau sebagai sikap konsumen terhadap merek atau perusahaan (Monferrer et al., 2019). Loyalitas konsumen penting bagi konsumen dan juga penyedia produk atau jasa. Konsumen yang setia akan melakukan pembelian berulang terhadap produk yang mereka antisipasi dari produsen yang sama yang akan menciptakan nilai keseluruhan untuk produsen (Hossain, 2019).

\subsection{Hipotesis Penelitian}

Atribut keamanan yang kuat meningkatkan tingkat kepuasan pelanggan (Guo et al., 2012). Mereka pun telah membuktikan bahwa keamanan dan kepuasan konsumen berhubungan secara positif. Beberapa penelitian menyatakan bahwa konsumen akan melanjutkan transaksi mereka di internet apabila keamanan data dan informasi mereka terjaga dengan baik. Oleh karena itu, keamanan dalam melakukan transaksi online adalah faktor yang menentukan konsumen melakukan transaksi online atau tidak (Hila Luding dan Cheng, 2014). Di luar persepsi mengenai keamanan yang beragam bagi konsumen, produsen perlu untuk meyakinkan konsumen bahwa informasi dan transaksi yang mereka lakukan sangat aman (Ishak, 2012).

Menurut Ahmad dan Al-Zu'bi (2011), keamanan memiliki pengaruh yang signifikan terhadap kepuasan konsumen. Mereka pun telah membuktikan bahwa antara keamanan dan kepuasan konsumen, ada hubungan yang positif. Sobihah et al. (2015), juga telah turut membuktikan bahwa keamanan termasuk dalam salah satu faktor yang mendukung kualitas layanan, memberikan pengaruh secara positif terhadap kepuasan konsumen. Melalui penelitian Elbeltagi dan Agag (2016), dibuktikan bahwa keamanan memiliki hubungan positif dengan kepuasan konsumen. Agag et al. (2016) juga membuktikan bahwa keamanan memiliki hubungan positif dengan kepuasan konsumen. Dari hal ini, hipotesis penelitian dapat disampaikan sebagai berikut:

\section{H1a: Ada hubungan antara keamanan dengan kepuasan konsumen secara positif.}


Berbeda dengan penjualan di toko tradisional dimana konsumennya dapat melihat produknya secara langsung setelah pembelian, e-grocery membutuhkan beberapa operasi logistik yang penting tidak hanya untuk pengantaran barang dengan tepat, tetapi juga untuk kepuasan dari pelanggan (Pan et al., 2017). E-grocery dalam penelitian ini dimaksudkan adalah cara Grab dalam memenuhi kebutuhan konsumen. Menurut Limbu et al. (2011), kepuasan pelanggan berhubungan dengan persepsi dari konsumen terhadap produsen. Kepuasan akan naik apabila persepsi konsumen menjadi positif dan akan menurun apabila persepsi konsumen menjadi negatif.

Sumit et al. (2013) membuktikan bahwa pemenuhan layanan berpengaruh positif terhadap kepuasan konsumen. Dalam studi Ting et al. (2016), dapat dibuktikan bahwa pemenuhan layanan yang merupakan salah satu faktor dalam kualitas pelayanan berpengaruh secara positif terhadap kepuasan konsumen. Lee dan Wong (2015) menyatakan bahwa pemenuhan layanan berpengaruh positif terhadap kepuasan konsumen. Agag et al. (2016) membuktikan dalam penelitiannya bahwa pemenuhan layanan memiliki hubungan yang positif dengan kepuasan konsumen. Abbasi et al. (2010) menyatakan bahwa pemenuhan layanan berpengaruh positif dengan kepuasan konsumen. Oleh karena itu, hipotesis penelitian adalah sebagai berikut:

\section{H1b: Ada hubungan antara pemenuhan layanan dengan kepuasan konsumen secara positif.}

Beberapa penelitian menyatakan bahwa pemenuhan layanan adalah masalah etika yang penting, yang berdampak pada kesetiaan konsumen. Dengan setiap pesanan yang terpenuhi dengan baik, akan mendorong konsumen untuk lebih setia terhadap suatu produk atau perusahaan. Clifford dan Lang (2012) telah membuktikan bahwa pemenuhan suatu layanan berpengaruh positif terhadap loyalitas konsumen. Long et al. (2012) menyatakan bahwa pemenuhan layanan memiliki hubungan yang positif dengan loyalitas konsumen. Khumbar (2011) membuktikan bahwa pemenuhan layanan memiliki hubungan positif dengan loyalitas konsumen. Shala dan Balaj (2016) juga telah membuktikan bahwa pemenuhan layanan memiliki hubungan positif terhadap loyalitas konsumen. Menurut Dubey dan Srivastava (2016), pemenuhan layanan adalah salah satu faktor di dalam kualitas layanan yang memiliki hubungan positif dengan loyalitas konsumen. Oleh karena itu, dapat diambil hipotesis:

H1c: Ada hubungan antara pemenuhan layanan dengan loyalitas konsumen secara positif.

Hasil penelitian memeprlihatkan bahwa tindakan penipuan ataupun iklan penipuan mengarahkan konsumen untuk membuat penilaian yang salah dan konsekuensinya adalah kepercayaan dan niat perilaku konsumen (Agag, 2017). Kepuasan konsumen adalah respon terhadap kesesuaian antara ekspektasi konsumen dan kenyataan dari layanan produk tersebut (Limbu et al., 2017). Menurut Roman (2010), tindakan pengelabuan memiliki hubungan negatif dengan kepuasan konsumen. Oleh karena itu, dapat dibuktikan melalui penelitian Roman bahwa tindakan bukan pengelabuan memiliki hubungan positif dengan kepuasan konsumen. Hal ini juga didukung oleh Riquelme et al. (2016) yang mengatakan bahwa tindakan bukan pengelabuan memiliki hubungan positif dengan kepuasan konsumen. Elbeltagi dan Agag (2016) membuktikan bahwa tindakan bukan pengelabuan memiliki hubungan positif dengan kepuasan konsumen. Agag et al. (2016) membuktikan bahwa tindakan bukan pengelabuan memiliki hubungan positif dengan kepuasan konsumen.

H2a: Ada hubungan antara bukan pengelabuan dengan kepuasan konsumen secara positif. 
Studi menunjukkan bahwa kebanyakan penyedia layanan melakukan klaim palsu dan berlebihan yang mengakibatkan ketidakjujuran dan memunculkan bahwa penyedia layanan yang tidak melakukan ketidakjujuran tersebut menikmati hasil yang lebih daripada yang melakukan ketidakjujuran. Hal ini membuktikan bahwa tingkat kejujuran yang lebih tinggi dikaitkan dengan perilaku yang kurang menguntungkan, mengurangi rasio pembelian terhadap suatu produk (Iqbal and Siddiqui, 2019). Sehingga dapat diperoleh hipotesis:

Menurut Javed et al. (2014), salah satu faktor yang membangun kepercayaan konsumen adalah ketiadaan pengelabuan, dan kepercayaan konsumen memiliki hubungan yang positif dengan loyalitas konsumen. Menurut Roman (2010), tindakan pengelabuan memiliki hubungan yang negatif dengan loyalitas konsumen secara tidak langsung dengan kepuasan konsumen sebagai mediator. Oleh karena itu, tindakan bukan pengelabuan memiliki hubungan dengan loyalitas konsumen secara positif, menurut Roman. Menurut Long et al. (2012), tindakan bukan pengelabuan merupakan salah satu faktor yang memiliki hubungan positif dengan loyalitas konsumen.

\section{H2b: Ada hubungan antara bukan pengelabuan dengan loyalitas konsumen secara positif.}

Keleluasaan pribadi (privacy) menjadi hal yang diperhatikan konsumen saat menurut mereka informasi mereka diminta tanpa izin mereka atau bagaimana informasi mereka dipergunakan (Wahab et al., 2011). Dengan adanya penjagaan terhadap informasi pribadi konsumen yang tertera dengan jelas pada privacy policy, konsumen akan merasa lebih aman dan berani untuk melakukan transaksi secara online dan menggunakan platform yang disediakan. Dalam studi Clifford dan Lang (2012), dinyatakan bahwa privasi konsumen menjadi salah satu faktor yang mendukung loyalitas konsumen. Sarwar et al. (2012) membuktikan bahwa privasi yang merupakan salah satu faktor yang mendukung kepercayaan konsumen berpengaruh positif terhadap loyalitas konsumen. Begitu pula dengan Dhiranty et al. (2017) yang menyatakan bahwa kepercayaan konsumen yang dibangun oleh salah satunya privasi, berpengaruh positif terhadap loyalitas konsumen. Long et al. (2012) melalui penelitiannya membuktikan bahwa privasi memiliki hubungan positif dengan loyalitas konsumen. Menurut penelitian Wahab et al. (2011), privasi memiliki hubungan positif dengan loyalitas konsumen.

\section{H2c: Ada hubungan antara privasi dengan loyalitas konsumen secara positif.}

Beberapa peneliti menyatakan bahwa kepuasan sebagai anteseden terhadap niat kesetiaan. Dengan demikian, tingginya kepuasan akan mengarahkan kepada kesetiaan yang positif (Abbes et al., 2020). Kepuasan konsumen didasarkan pada konsep memuaskan kebutuhan dan ekspektasi untuk membangun kesetiaan dan merupakan prasyarat untuk pembelian di masa depan (Hossain, 2019). Kepuasan konsumen menjadi salah satu faktor yang mendukung konsumen untuk setia terhadap suatu produk/jasa. Karena dengan konsumen yang puas, akan mendorong konsumen untuk tidak beralih ke produk yang lain (Hossain et al., 2018). Dengan begitu, hipotesis yang didapat adalah:

Lee dan Wong (2015) membuktikan bahwa kepuasan konsumen berpengaruh positif terhadap loyalitas konsumen. Sobihah et al. (2015) membuktikan bahwa kepuasan konsumen berpengaruh positif terhadap loyalitas konsumen. Yulisetiarini (2016) menyatakan bahwa kepuasan konsumen memiliki hubungan yang positif dengan loyalitas konsumen. Ganiyu et al. 
(2012) membuktikan bahwa kepuasan konsumen berpengaruh positif terhadap loyalitas konsumen, dibantu dengan faktor-faktor pendukung lainnya. Menurut penelitian dari Md Ariff et al. (2013), kepuasan konsumen dengan loyalitas konsumen memiliki hubungan yang positif.

H3: Ada hubungan antara kepuasan konsumen dengan loyalitas konsumen secara positif.

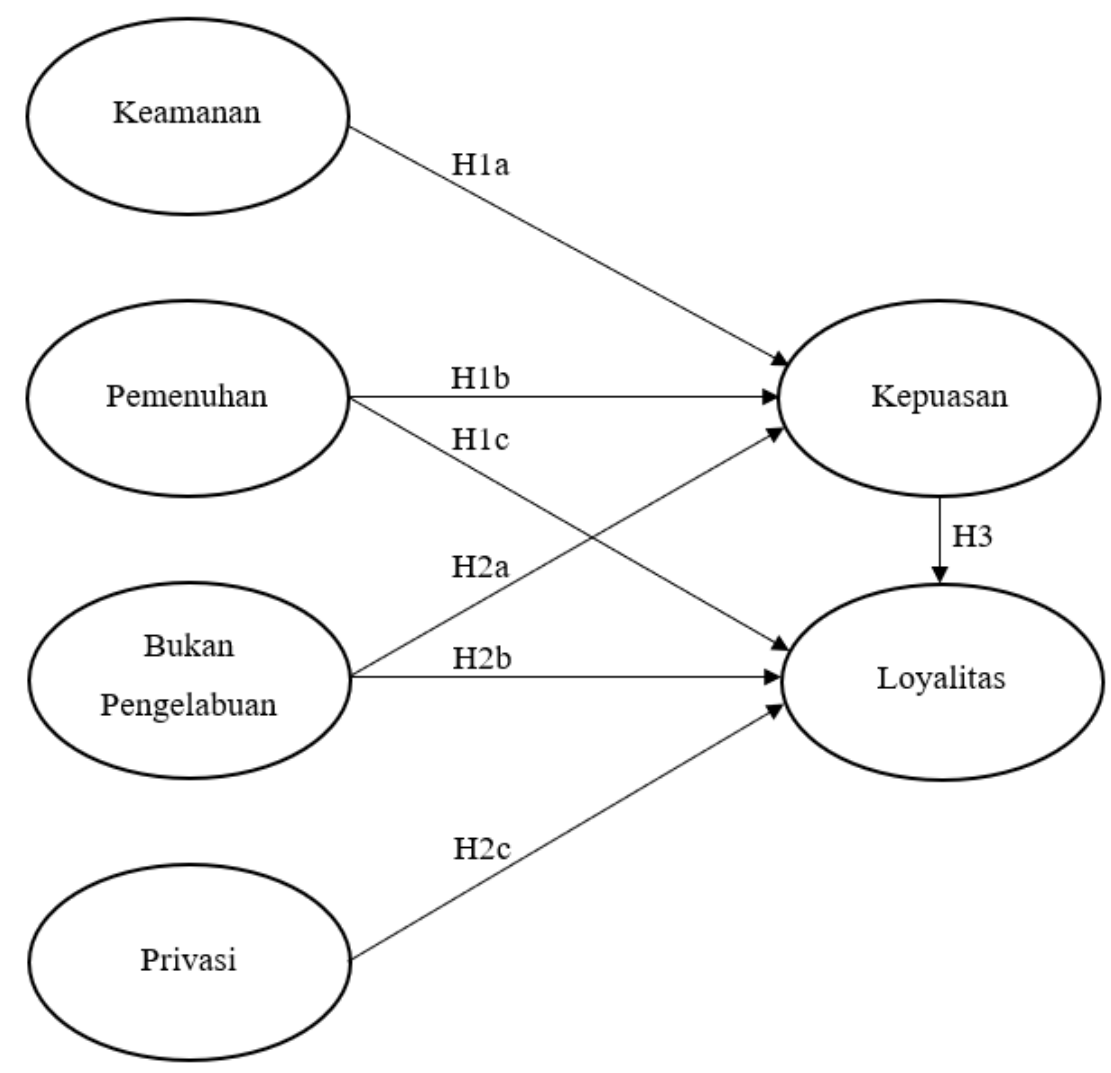

Sumber: Limbu et al. (2011)

\section{Gambar 1. Model Konseptual}

\section{METODOLOGI PENELITIAN}

Penelitian ini merupakan penelitian kuantitatif yang dalam pengoperasiannya menggunakan data berupa angka. Metodologi kuantitatif berkaitan dengan upaya untuk mengukur fenomena sosial dan mengumpulkan dan menganalisis data numerik, dan fokus pada tautan di antara sejumlah kecil atribut di banyak kasus (Antwi dan Hamza, 2015). Penelitian ini adalah penelitian deskriptif dimana bertujuan untuk menggambarkan suatu fenomena dan karakteristiknya; lebih mementingkan "apa" dibandingkan "bagaimana atau mengapa" sesuatu dapat terjadi (Nassaji, 2015). Penelitian deskriptif juga bertujuan untuk menguji hipotesis penelitian (Sekaran dan Bougie, 2016). 
Teknik sampling yang digunakan ialah sampling bertujuan (purposive) yang merupakan sampling nonprobabilitas. Secara spesifik, kriteria responden adalah (1) mahasiswa yang tinggal di Jabodetabek dan (2) telah menggunakan layanan GrabFood setidaknya tiga kali. Peneliti memilih mahasiswa Jabodetabek dikarenakan mahasiswa merupakan salah satu pengguna terbanyak layanan GrabFood, sedangkan Jabodetabek dipilih karena merupakan daerah yang kemajuan teknologi dan akses akan teknologi tersebut lebih pesat. Jumlah sampel yang direncanakan pada penelitian ini adalah sebanyak 120 orang.

Semua indikator penelitian berasal dari penelitian sebelumnya (Tabel 1). Skala Likert 5 poin digunakan dalam pengukuran ini. Sebelum data dianalisis, uji reliabilitas dan uji validitas dilakukan. Dalam uji reliabilitas, peneliti menggunakan internal consistency reliability atau biasa disebut reliabilitas Cronbach Alpha (Bonett dan Wright, 2014). Menurut Ursachi et al. (2015), pengukuran koefisien Cronbach Alpha dianggap secara tidak langsung mengindikasikan sejauh mana serangkaian item mengukur konstruk laten unidimensional tunggal. Sebuah tes dikatakan dapat diandalkan jika meminimalkan kesalahan pengukuran sehingga kesalahan tersebut tidak sangat berkorelasi dengan skor sebenarnya dan pada saat yang sama, hubungan antara skor sejati dan yang diamati harus kuat.

Dalam menguji validitas, peneliti menggunakan construct validity untuk memeriksa apa yang mendasari konstruk sebenarnya diukur. Menurut Ursachi et al. (2015), dalam construct validity, yang diukur ialah validitas konvergen dan diskriminan. Validitas konvergen mengukur sejauh mana dua instrumen pada konstruk yang sama saling terkait, dan konvergensi ditemukan ketika kedua instrumen yang dianalisis sangat berkorelasi. Validitas diskriminan mengukur sejauh mana dua langkah yang dirancang untuk mengukur serupa, tetapi konstruk berbeda secara konseptual terkait, diskriminan terbukti ketika korelasi berada pada tingkat rendah ke sedang.

Pengujian hipotesis dilakukan dengan structural equation modeling dengan software PLS. Pendekatan bootstrapping, yaitu metode resampling nonparametrik yang memotong asumsi normalitas yang biasa dilakukan pada tes mediasi tradisional dan karenanya lebih kuat, terutama dengan sampel yang lebih kecil (Preacher dan Hayes, 2004; 2008 dalam Hoge et al., 2014). Penggunaan pendekatan ini juga didasarkan pada Rungtusanatham et al. (2014) yang menyarankan untuk menggunakan Bias-Corrected Bootstrapping jika jumlah sampel lebih besar dari 100.

Tabel 1. Pengukuran Variabel

\begin{tabular}{|l|l|l|l|c|}
\hline Variabel & \multicolumn{1}{|c|}{ Definisi Konseptual } & \multicolumn{1}{c|}{ Definisi Operasional } & Skala & Sumber \\
\hline $\begin{array}{l}\text { Keamanan } \\
(\mathrm{Se})\end{array}$ & $\begin{array}{l}\text { Keamanan didefinisikan sebagai } \\
\text { perlindungan suatu data dari pihak- } \\
\text { pihak yang tidak bertanggungjawab } \\
\text { atau tidak berhak (Chiu } \text { et al., } \\
\text { 2017). }\end{array}$ & $\begin{array}{l}\text { 1. Kebijakan keamanan } \\
\text { mudah dimengerti. } \\
\text { 2. Situs menampilkan } \\
\text { 'Syarat dan Ketentuan' } \\
\text { transaksi online sebelum } \\
\text { pembelian dilakukan. } \\
\text { 3. Situs ini menawarkan } \\
\text { metode pembayaran yang } \\
\text { aman. }\end{array}$ & Likert & $\begin{array}{l}\text { Román (2007, } \\
\text { dalam Limbu } \\
\text { et al., 2011). }\end{array}$ \\
\hline
\end{tabular}




\begin{tabular}{|c|c|c|c|c|}
\hline & & $\begin{array}{l}\text { 4. Situs ini memiliki fitur } \\
\text { keamanan yang memadai. }\end{array}$ & & \\
\hline $\begin{array}{l}\text { Pemenuhan } \\
\text { (F) }\end{array}$ & $\begin{array}{l}\text { Istilah pemenuhan mengacu pada } \\
\text { pengiriman pembelian online yang } \\
\text { tepat waktu dan akurat, representasi } \\
\text { produk, serta fungsi situs web yang } \\
\text { tepat (Limbu et al., 2011). }\end{array}$ & $\begin{array}{l}\text { 1. Harga yang tertera di situs } \\
\text { adalah tagihan sebenarnya. } \\
\text { 2. Saya mendapatkan apa } \\
\text { yang saya pesan dari situs } \\
\text { ini. } \\
\text { 3. Produk yang saya terima } \\
\text { sesuai dengan apa yang saya } \\
\text { pesan. } \\
\text { 4. Produk yang saya pesan } \\
\text { sampai tepat waktu. }\end{array}$ & Likert & $\begin{array}{c}\text { Román } \\
\text { (2007, dalam } \\
\text { Limbu et al., } \\
\text { 2011). }\end{array}$ \\
\hline $\begin{array}{l}\text { Bukan } \\
\text { Pengelabuan } \\
\text { (N) }\end{array}$ & $\begin{array}{l}\text { Bukan pengelabuan mengacu pada } \\
\text { keyakinan konsumen bahwa } \\
\text { penyedia layanan elektronik tidak } \\
\text { akan melakukan penipuan untuk } \\
\text { mempengaruhi konsumen dalam } \\
\text { melakukan transaksi pada suatu } \\
\text { produk (Elbeltagi dan Agag, 2016). }\end{array}$ & $\begin{array}{l}\text { 1. Situs ini melebih-lebihkan } \\
\text { manfaat dan karakteristik } \\
\text { dari penawarannya. } \\
\text { 2. Situs ini mengambil } \\
\text { keuntungan dari konsumen } \\
\text { yang kurang berpengalaman } \\
\text { untuk melakukan } \\
\text { pembelian. } \\
\text { 3. Situs ini mencoba } \\
\text { membujuk saya untuk } \\
\text { membeli produk yang bukan } \\
\text { intensi saya. }\end{array}$ & Likert & $\begin{array}{c}\text { Román } \\
\text { (2007, dalam } \\
\text { Limbu et al., } \\
\text { 2011). }\end{array}$ \\
\hline $\begin{array}{l}\text { Privasi } \\
\text { (P) }\end{array}$ & $\begin{array}{l}\text { Masalah privasi merujuk pada } \\
\text { tingkat kecemasan konsumen } \\
\text { tentang kemungkinan informasi } \\
\text { pribadi, rahasia atau sensitif } \\
\text { konsumen dapat dipantau, diekspos } \\
\text { atau disalahgunakan oleh orang lain } \\
\text { di luar maupun di dalam jaringan } \\
\text { (Malik et al., 2020). }\end{array}$ & $\begin{array}{l}\text { 1. Situs ini menjelaskan } \\
\text { bagaimana informasi } \\
\text { pengguna digunakan. } \\
\text { 2. Informasi yang perlu } \\
\text { disediakan hanya informasi } \\
\text { pribadi yang penting untuk } \\
\text { menyelesaikan transaksi. } \\
\text { 3. Informasi mengenai } \\
\text { kebijakan privasi disajikan } \\
\text { dengan jelas. }\end{array}$ & Likert & $\begin{array}{l}\text { Román (2007, } \\
\text { dalam Limbu } \\
\text { et al., 2011). }\end{array}$ \\
\hline $\begin{array}{l}\text { Kepuasan } \\
\text { (Sa) }\end{array}$ & $\begin{array}{l}\text { Kepuasan konsumen adalah } \\
\text { penilaian terhadap fitur produk atau } \\
\text { jasa, atau produk atau jasa itu } \\
\text { sendiri, memberikan pemenuhan } \\
\text { konsumsi yang menyenangkan atau } \\
\text { kurang/terlalu berlebihan } \\
\text { (Monferrer } \text { et al., 2019). }\end{array}$ & $\begin{array}{l}\text { 1. Saya senang saya } \\
\text { melakukan pembelian di } \\
\text { situs ini. } \\
\text { 2. Pilihan saya untuk } \\
\text { membeli dari situs ini adalah } \\
\text { pilihan yang bijaksana. } \\
\text { 3. Saya puas dengan } \\
\text { keputusan saya untuk } \\
\text { membeli dari situs ini. } \\
\text { 4. Situs ini BELUM pernah } \\
\text { mengecewakan saya. }\end{array}$ & Likert & $\begin{array}{l}\text { Anderson dan } \\
\text { Srinivasan } \\
\text { (2003, dalam } \\
\text { Limbu et al., } \\
\text { 2011). }\end{array}$ \\
\hline
\end{tabular}




\begin{tabular}{|c|c|c|c|c|}
\hline $\begin{array}{l}\text { Loyalitas } \\
\text { (L) }\end{array}$ & $\begin{array}{l}\text { Kesetiaan konsumen dapat } \\
\text { didefinisikan dalam hal perilaku } \\
\text { pembelian berulang atau sebagai sikap } \\
\text { konsumen terhadap merek atau } \\
\text { perusahaan (Monferrer } \text { et al., 2019). }\end{array}$ & $\begin{array}{l}\text { 1. Saya mendorong kerabat } \\
\text { untuk melakukan pembelian } \\
\text { di situs ini. } \\
\text { 2. Saya mengatakan hal-hal } \\
\text { positif tentang situs web } \\
\text { kepada orang lain. } \\
\text { 3.Saya akan melakukan } \\
\text { lebih banyak pembelian di } \\
\text { situs dalam beberapa waktu } \\
\text { mendatang. } \\
\text { 4. Saya akan } \\
\text { merekomendasikan situs ini } \\
\text { kepada seseorang yang } \\
\text { meminta saran saya. } \\
\text { 5. Situs ini adalah pilihan } \\
\text { pertama saya untuk membeli } \\
\text { produk yang sejenis dengan } \\
\text { produk yang baru-baru ini } \\
\text { saya beli secara } \\
\text { konvensional. }\end{array}$ & Likert & $\begin{array}{l}\text { Román (2007, } \\
\text { dalam Limbu } \\
\text { et al., 2011). }\end{array}$ \\
\hline
\end{tabular}

\section{HASIL DAN PEMBAHASAN}

Terdapat 101 kuesioner yang dapat digunakan dari 120 kuesioner yang didistribusikan. Profil responden yang keseluruhan adalah mahasiswa sebagai berikut: jenis kelamin pria sebesar 40,59 persen (41 responden) dan wanita sebesar 59,41 persen (60 responden). Lebih lanjut, responden yang berada pada rentang usia 16 hingga 20 tahun sebesar 54,45 persen dan rentang usia 21 hingga 25 tahun sebesar 45,55 persen.

Peneliti menggunakan SmartPLS 3 (Ringle, Wende, dan Becker, 2015) untuk melakukan penghitungan melalui PLS-SEM yang menghasilkan measurement model dari uji reliabilitas, validitas konvergen, dan validitas diskriminan.

Tabel 2. Hasil Uji Reliabilitas dan Validitas Konvergen

\begin{tabular}{|ccccc|}
\hline Indikator & $\begin{array}{c}\text { Outer } \\
\text { Loadings }\end{array}$ & $\begin{array}{c}\text { Cronbach's } \\
\text { Alpha }\end{array}$ & $\begin{array}{c}\text { Composite } \\
\text { Reliability }\end{array}$ & AVE \\
Keamanan & & 0,719 & 0,826 & 0,544 \\
$\operatorname{Se} 1$ & 0,759 & & \\
$\operatorname{Se} 2$ & 0,693 & & \\
$\operatorname{Se} 3$ & 0,705 & & \\
$\operatorname{Se} 4$ & 0,790 & & \\
\hline
\end{tabular}




\begin{tabular}{|c|c|c|c|c|}
\hline Pemenuhan & & 0,739 & 0,836 & 0,563 \\
\hline $\mathrm{F} 1$ & 0,657 & & & \\
\hline $\mathrm{F} 2$ & 0,828 & & & \\
\hline F3 & 0,762 & & & \\
\hline $\mathrm{F} 4$ & 0,744 & & & \\
\hline Bukan Pengelabuan & & 0,733 & 0,849 & 0,653 \\
\hline $\mathrm{N} 1$ & 0,744 & & & \\
\hline $\mathrm{N} 2$ & 0,794 & & & \\
\hline N3 & 0,881 & & & \\
\hline Privasi & & 0,784 & 0,872 & 0,694 \\
\hline $\mathrm{P} 1$ & 0,771 & & & \\
\hline $\mathrm{P} 2$ & 0,843 & & & \\
\hline P3 & 0,882 & & & \\
\hline Kepuasan & & 0,760 & 0,863 & 0,678 \\
\hline Sa1 & 0,866 & & & \\
\hline $\mathrm{Sa} 2$ & 0,847 & & & \\
\hline $\mathrm{Sa} 3$ & 0,752 & & & \\
\hline $\mathrm{Sa} 4$ & 0,472 & & & \\
\hline Loyalitas & & 0,837 & 0,887 & 0,611 \\
\hline L1 & 0,694 & & & \\
\hline L2 & 0,740 & & & \\
\hline L3 & 0,801 & & & \\
\hline
\end{tabular}




$\begin{array}{ll}\text { L4 } & 0,829 \\ \text { L5 } & 0,823\end{array}$

Tabel 2 menunjukkan hasil uji reliabilitas konsistensi internal dan validitas konvergen. Hasil uji reliabilitas konsistensi internal menyatakan bahwa setiap variabel dinyatakan reliabel atau konsisten karena telah melampaui syarat nilai Cronbach's Alpha $\geq 0,7$, yaitu dengan rentang nilai 0,719-0,837. Hasil Outer Loadings (OL) dengan rentang 0,40-0,70 perlu dihapuskan jika berkontribusi pada peningkatan nilai Composite Reliability (CR) dan Average Variance Extracted (AVE) (Hamid et al., 2017) sehingga indikator Sa4 dengan nilai OL 0,472 dihapuskan karena berkontribusi meningkatkan nilai Cronbach's Alpha dari 0,700 menjadi 0,760.

Hasil uji validitas konvergen merupakan penilaian untuk mengukur tingkat korelasi berbagai indikator dengan konstruk yang sama melalui pertimbangan pada nilai OL, CR, dan AVE $(>0,50)$ (Hamid et al., 2017). Hasil uji validitas konvergen dinyatakan valid karena nilai AVE seluruh variabel berada pada rentang 0,544-0,694.

Tabel 3. Hasil Uji Korelasi (Fornell-Larcker Criterion)

\begin{tabular}{|l|c|c|c|c|l|l|}
\hline & Pemenuhan & Loyalitas & $\begin{array}{c}\text { Bukan } \\
\text { Penipuan }\end{array}$ & Privasi & Kepuasan & Keamanan \\
\hline Pemenuhan & $\mathbf{0 , 7 5 0}$ & & & & & \\
\hline Loyalitas & 0,514 & $\mathbf{0 , 7 7 9}$ & & & & \\
\hline $\begin{array}{l}\text { Bukan } \\
\text { Penipuan }\end{array}$ & 0,391 & 0,473 & $\mathbf{0 , 8 0 8}$ & & & \\
\hline Privasi & 0,424 & 0,343 & 0,373 & $\mathbf{0 , 8 3 3}$ & & \\
\hline Kepuasan & 0,320 & 0,569 & 0,409 & 0,464 & $\mathbf{0 , 8 2 3}$ & \\
\hline Keamanan & 0,483 & 0,481 & 0,514 & 0,704 & 0,542 & $\mathbf{0 , 7 3 8}$ \\
\hline
\end{tabular}

Tabel 3 merupakan hasil uji korelasi (Fornell-Larcker Criterion) yang digunakan untuk menentukan validitas diskriminan. Validitas diskriminan mengacu pada sejauh mana konstruk tersebut berbeda satu sama lain secara empiris dengan melihat nilai cross-loading, maka indikator factor loading pada konstruk yang ditetapkan harus lebih tinggi daripada semua loading konstruk lainnya dengan ketentuan bahwa nilai cut-off factor loading lebih tinggi dari 0,70 (Hamid et al., 2017). Dengan demikian, validitas diskriminan dinyatakan tercapai, yaitu nilai masing-masing variabel berada pada rentang 0,738-0,833. Hasil dari uji reliabilitas dan validitas yang telah tercapai kemudian menghasilkan measurement model pada Gambar 2. 
Gambar 2. Measurement Model dan Structural Model

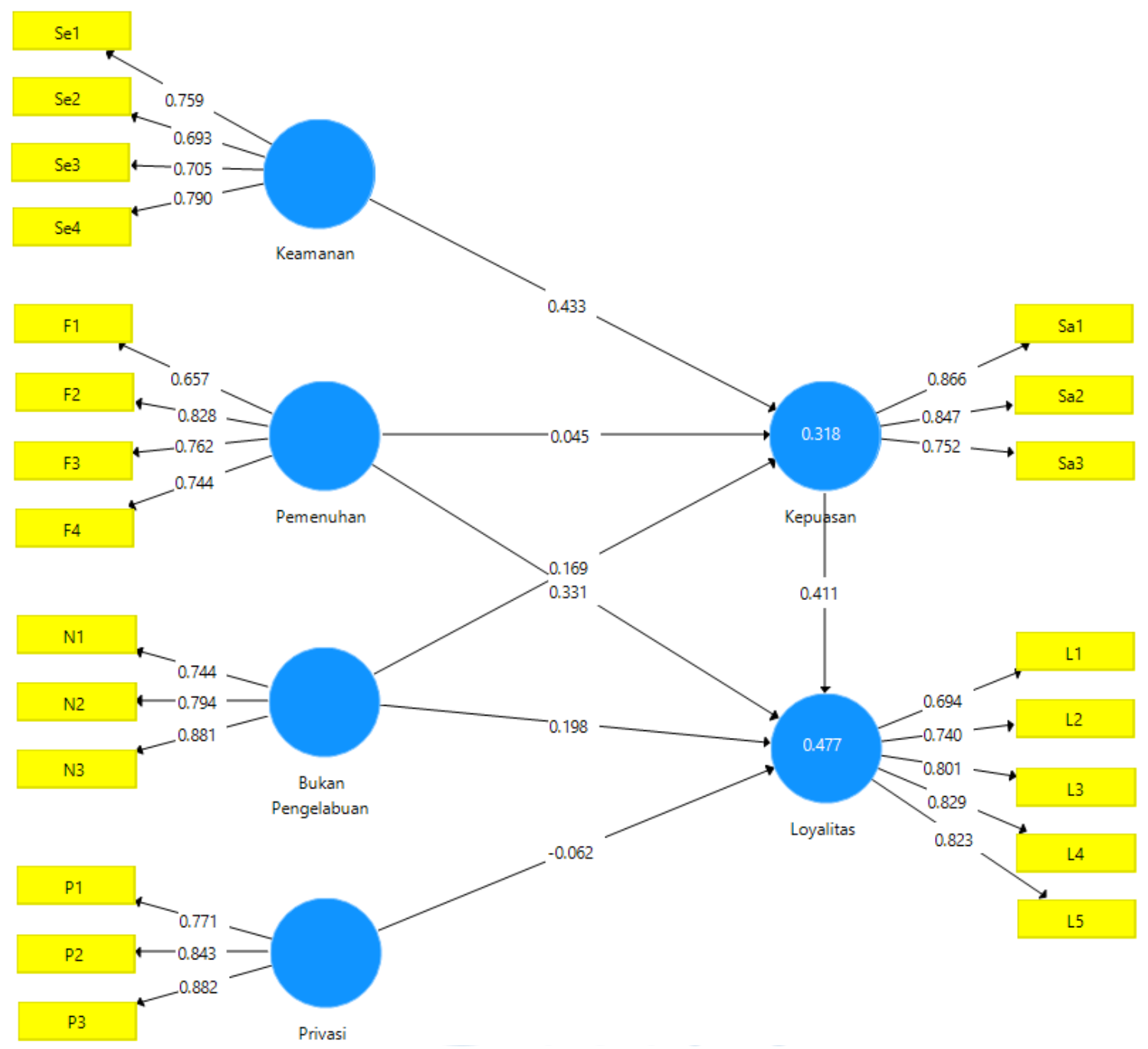

\subsection{Analisis Structural Model.}

Penelitian ini menggunakan model persamaan struktural (SEM) untuk menguji adanya saling ketergantungan secara teoritis antara kepuasan (Sa) dan loyalitas (L). Berdasarkan Gambar 2, diketahui bahwa keamanan (Se) memiliki efek yang kuat terhadap kepuasan (Sa). Sedangkan, pemenuhan $(\mathrm{F})$ dan bukan pengelabuan $(\mathrm{N})$ memiliki efek yang lebih lemah terhadap kepuasan $(\mathrm{Sa})$. Akan tetapi, baik pemenuhan $(\mathrm{F})$ maupun bukan pengelabuan $(\mathrm{N})$ mempunyai efek yang lebih kuat terhadap loyalitas (L) secara langsung. Efek dari privasi (P) terhadap loyalitas (L) menunjukkan angka yang kecil yang berarti kurang berpengaruh terhadap loyalitas (L). Kepuasan (S) terhadap loyalitas (L) menunjukkan adanya efek yang kuat, dengan nilai tertinggi kedua setelah keamanan (Se) terhadap kepuasan (Sa).

Signifikansi hubungan seluruh variabel diuji menggunakan Bias-Corrected Bootstrapping dalam PLS dengan tipe two-tailed dan pada level signifikan 0,05. Hasil uji hipotesis seperti disajikan pada Tabel 5, menunjukkan hipotesis yang didukung dan tidak didukung yang dilihat 
dari nilai $t$-statistics dan $p$-value. Batas untuk $t$-statistics adalah $\pm 1,96$ dan $p$-value sebesar 0,05 . Hipotesis yang didukung ialah H1a, H1c, H2a, H2b, dan H3, sedangkan hipotesis yang tidak didukung ialah $\mathrm{H} 1 \mathrm{~b}$ dan $\mathrm{H} 2 \mathrm{c}$.

Tabel 4. Total Efek

Hipotesis $\begin{gathered}\text { Hubungan } \\ \text { Variabel }\end{gathered} \quad \begin{gathered}\text { Standard } \\ \text { Deviation }\end{gathered} \quad$ T-statistics $\quad$ P-value $\quad$ Kesimpulan

Faktor yang mempengaruhi Kepuasan (Sa)

$\begin{array}{llllll}\text { H1a } & \mathrm{Se} \rightarrow \mathrm{Sa} & 0,112 & 3,873 & 0,000 & \text { Didukung } \\ \mathrm{H} 1 \mathrm{~b} & \mathrm{~F} \rightarrow \mathrm{Sa} & 0,085 & 0,527 & 0,598 & \text { Tidak Didukung } \\ \mathrm{H} 1 \mathrm{c} & \mathrm{N} \rightarrow \mathrm{Sa} & 0,084 & 2,013 & 0,045 & \text { Didukung }\end{array}$

Faktor yang mempengaruhi Loyalitas (L)

\begin{tabular}{llllll}
$\mathrm{H} 2 \mathrm{a}$ & $\mathrm{F} \rightarrow \mathrm{L}$ & 0,081 & 4,300 & 0,000 & Didukung \\
\hline $\mathrm{H} 2 \mathrm{~b}$ & $\mathrm{~N} \rightarrow \mathrm{L}$ & 0,088 & 3,029 & 0,003 & Didukung \\
\hline $\mathrm{H} 2 \mathrm{c}$ & $\mathrm{P} \rightarrow \mathrm{L}$ & 0,100 & 0,625 & 0,532 & Tidak Didukung
\end{tabular}

Faktor yang memediasi Loyalitas (L)
H3
$\mathrm{Sa} \rightarrow \mathrm{L}$
0,081
5,093
0,000
Didukung

Berdasarkan Tabel 4, suatu signifikansi dihasilkan, yaitu berupa bukti bahwa ada hubungan dari variabel-variabel yang diteliti. H1a dengan nilai t-statistics 3,873 dan p-value 0,000 membuktikan bahwa ada hubungan positif antara keamanan fitur layanan GrabFood dengan kepuasan terhadap layanan GrabFood. H1b dengan nilai t-statistics 0,527 dan p-value 0,598 menyatakan bahwa tidak ada hubungan positif antara pemenuhan ekspektasi konsumen GrabFood dengan kepuasan terhadap layanan GrabFood. H1c dengan nilai t-statistics 2,013 dan p-value 0,045 membuktikan adanya hubungan positif antara bukan pengelabuan atau kejujuran pada layanan GrabFood dengan kepuasan konsumen terhadap layanan GrabFood.

Kemudian, $\mathrm{H} 2 \mathrm{a}$ dengan nilai $t$-statistics 4,300 dan p-value 0,000 membuktikan adanya hubungan yang positif antara pemenuhan akan ekspektasi konsumen dengan loyalitas konsumen terhadap layanan GrabFood. H2b dengan nilai $t$-statistics 3,029 dan p-value 0,003 menunjukkan hubungan yang positif antara bukan pengelabuan dengan loyalitas konsumen terhadap layanan GrabFood. H2c dengan nilai $t$-statistics 0,625 dan p-value 0,532 menunjukkan bahwa tidak ada hubungan positif antara privasi akan informasi konsumen di layanan GrabFood dengan loyalitas konsumen terhadap layanan GrabFood. H3 dengan nilai t-statistics 5,093 dan p-value 0,000 menunjukkan bahwa ada hubungan positif antara kepuasan konsumen dengan loyalitas konsumen terhadap layanan GrabFood. 
Tabel 5. Nilai R-Square $\left(\mathbf{R}^{2}\right)$

\begin{tabular}{|l|c|c|}
\hline & R-Square $\left(\mathbf{R}^{\mathbf{2}}\right)$ & R-Square $\left(\mathbf{R}^{\mathbf{2}}\right)$ Adjusted \\
\hline Kepuasan & 0,318 & 0,297 \\
\hline Loyalitas & 0,477 & 0,455 \\
\hline
\end{tabular}

Tabel 5 menunjukkan nilai $\mathrm{R}^{2}$ sebesar 0,318 atau 31,8\% yang berarti bahwa tingkat penjelasan variansi data dari variabel kepuasan adalah sedang. Sedangkan, nilai $\mathrm{R}^{2}$ sebesar 0,477 atau $47 \%$ menunjukkan bahwa tingkat penjelasan variansi data dari variabel loyalitas lebih tinggi daripada variabel kepuasan.

Tabel 6. Specific Indirect Effect

\begin{tabular}{|l|c|c|c|c|c|}
\hline & $\begin{array}{c}\text { Original } \\
\text { Sample }\end{array}$ & $\begin{array}{c}\text { Sample } \\
\text { Mean }\end{array}$ & $\begin{array}{c}\text { Standard } \\
\text { Deviation }\end{array}$ & T-Statistics & P-values \\
\hline $\mathbf{N} \rightarrow \mathbf{S a} \rightarrow \mathbf{L}$ & 0,069 & 0,068 & 0,037 & 1,866 & 0,036 \\
\hline $\mathbf{S e} \rightarrow \mathbf{S a} \rightarrow \mathbf{L}$ & 0,178 & 0,176 & 0,059 & 3,008 & 0,003 \\
\hline $\mathbf{F} \rightarrow \mathbf{S a} \rightarrow \mathbf{L}$ & 0,018 & 0,022 & 0,034 & 0,536 & 0,592 \\
\hline
\end{tabular}

Tabel 6 menggambarkan hubungan tidak langsung diantara variabel bukan pengelabuan, keamanan, dan pemenuhan dengan loyalitas yang dimediasi oleh kepuasan. Hasil p-values mengindikasikan bahwa hanya hubungan variabel keamanan yang dimediasi melalui kepuasan secara tidak langsung signifikan terhadap loyalitas. Sedangkan, hubungan variabel bukan pengelabuan dan pemenuhan secara tidak langsung yang dimediasi kepuasan tidak signifikan terhadap loyalitas.

\subsection{Pembahasan}

Berdasarkan hasil analisis data dari 101 responden dengan jumlah responden yang seluruhnya adalah mahasiswa dengan jenis kelamin pria sebesar 40,59 persen (41 responden) dan wanita sebesar 59,41 persen (60 responden), berada pada rentang usia 16 hingga 20 tahun sebesar 54,45 persen dan rentang usia 21 hingga 25 tahun sebesar 45,55 persen, serta cakupan domisili Tangerang sebesar 68,31 persen, Jakarta sebesar 28,72 persen, Bogor sebesar 1,98 persen, dan Bekasi sebesar 0,99 persen, suatu signifikansi dihasilkan. Maka dari itu, hipotesis yang diajukan dapat terkonfirmasi baik didukung maupun tidak didukung.

H1a membuktikan ada hubungan positif antara keamanan fitur layanan GrabFood dengan kepuasan terhadap layanan GrabFood. Hasil ini konsisten dengan penelitian sebelumnya mengenai hubungan antara keamanan dan kepuasan oleh Ahmad dan Al-Zu'bi (2011), Agag et al. (2016), dan Agag (2019). Keamanan dalam hal ini mengacu pada kerahasiaan, keandalan, dan perlindungan informasi karena hal tersebut merupakan prasyarat penting agar e-commerce dapat berfungsi dengan baik (Agag, 2019). Konsumen menginginkan perusahaan e-commerce untuk mempunyai pernyataan akan perlindungan dan keamanan teknologinya (Agag et al., 2016). Dalam 
hal ini, keamanan dari GrabFood dapat berupa metode pembayaran yang mudah dan praktis tetapi juga jelas dan aman. Keamanan tersebut terkonfirmasi memiliki hubungan yang positif dengan kepuasan konsumen yang berarti semakin aman teknologi yang ditawarkan oleh GrabFood, semakin puas konsumen terhadap layanan GrabFood.

H1b dinyatakan tidak ada hubungan positif antara pemenuhan ekspektasi konsumen GrabFood dengan kepuasan terhadap layanan GrabFood. Hasil ini bertolak belakang dengan penelitian terdahulu oleh Lee dan Wong (2016), Ting et al. (2016), dan Agag et al. (2016) yang menunjukkan bahwa pemenuhan memiliki hubungan positif dengan kepuasan. Berdasarkan Ting et al. (2016), belanja online pada situs Business-to-Consumer (B2C) melibatkan pembeli yang mengakses situs web online untuk membeli produk, maka dari itu sejauh mana kebutuhan pembeli terpenuhi menjadi penting. Pemenuhan tidak memiliki hubungan yang positif terhadap kepuasan dapat dikarenakan produk yang didapatkan konsumen tidak sesuai ekspektasi akibat kesalahan dari pihak merchant sebagai pihak yang memproduksi produk berupa makanan maupun minuman yang dipesan konsumen. Sedangkan, layanan GrabFood sendiri hanya merupakan media penyalur antara pihak merchant dengan konsumen. Selain itu, berkaitan dengan ekspektasi ketepatan waktu pengiriman dapat dikarenakan sulitnya mendeteksi alamat konsumen yang disebabkan alamat yang tercantum pada peta GrabFood tidak detail dan akurat sehingga pengemudi yang mengantarkan pesanan harus bertanya pada orang sekitar terlebih dahulu.

H1c mengindikasikan ada hubungan positif antara bukan pengelabuan atau kejujuran pada layanan GrabFood dengan kepuasan konsumen terhadap layanan GrabFood. Hal ini konsisten dengan penelitian terdahulu oleh Agag (2019) dan Elbeltagi dan Agag (2019) yang menyatakan bahwa bukan pengelabuan berpengaruh positif pada kepuasan konsumen. Bukan pengelabuan ini mengacu pada sejauh mana konsumen percaya bahwa online retailer tidak melakukan praktik penipuan atau manipulatif yang bertujuan untuk membujuk konsumen membeli produk yang ditawarkan pada situs web (Agag et al., 2016). Menurut Agag et al. (2016) pula, dimensi ini berfokus pada persepsi konsumen akan praktik untuk penipuan bukan tindakan penipuan itu sendiri. Berdasarkan hal tersebut, layanan GrabFood sendiri memiliki sistem yang membantu konsumen untuk mendapatkan kembali dananya jika produk yang diterima tidak sesuai dengan yang dipesan, baik karena kesalahan pengemudi ataupun pihak merchant.

Kemudian, H2a membuktikan hubungan yang positif antara pemenuhan akan ekspektasi konsumen dengan loyalitas konsumen. Hasil ini juga serupa dengan hasil penelitian terdahulu oleh Clifford dan Lang (2012), Lu et al. (2013), dan Shala dan Balaj (2016) yang menyatakan bahwa ada hubungan positif antara pemenuhan dengan loyalitas konsumen. Menurut Jiang dan Rosenbloom (2005, dalam Shala dan Balaj, 2016), kepuasan terkait dengan waktu pengiriman dan keandalan tampaknya memiliki pengaruh yang besar pada kepuasan konsumen secara keseluruhan yang menumbuhkan niat untuk membeli kembali dari merek yang sama. Pemenuhan ekspektasi akan layanan GrabFood dengan loyalitas konsumen dinyatakan lebih tinggi nilainya jika dibandingkan dengan kepuasan konsumen. Hal ini berarti secara langsung, pemenuhan ekspektasi konsumen berdampak besar pada loyalitas walaupun kepuasan konsumen tidak tercapai. Menurut Román (2010), dalam konteks online yang di mana tersedia alternatif lain, maka mungkin bagi konsumen untuk merasa sangat puas tetapi tidak loyal. Hal tersebut berlaku sebaliknya, ketika konsumen kurang atau tidak puas, belum berarti konsumen tersebut tidak loyal. Akan tetapi, hal tersebut dapat didasari juga akan terbatasnya pilihan alternatif selain GrabFood. 
$\mathrm{H} 2 \mathrm{~b}$ menunjukkan bahwa ada hubungan positif antara bukan pengelabuan dan loyalitas konsumen. Hasil ini serupa atau konsisten dengan penelitian terdahulu oleh Lu et al. (2013) membuktikan bahwa hubungan bukan pengelabuan dengan loyalitas konsumen ialah positif. Bukan pengelabuan menggambarkan kekhawatiran konsumen yang dalam peralihan dari pasar tradisional ke pasar online melalui internet yang relatif tidak dikenal atau impersonal dikarenakan adanya praktik periklanan dan penjualan yang menipu atau manipulatif; kurangnya kesempatan untuk bertatap muka atau berinteraksi sehingga mengurangi kemampuan untuk mendeteksi adanya penipuan (Agag et al., 2016). Berdasarkan hasil penelitian, dapat dinyatakan bahwa layanan GrabFood dipercaya oleh konsumen sebagai layanan yang tidak manipulatif dan bertindak secara jujur atau transparan terhadap konsumennya. Kepercayaan konsumen akan layanan GrabFood inilah yang kemudian dapat membuat konsumen loyal atau setia terhadap layanan GrabFood.

$\mathrm{H} 2 \mathrm{c}$ menunjukkan bahwa tidak ada hubungan positif antara privasi akan informasi konsumen di layanan GrabFood dan loyalitas konsumen terhadap layanan GrabFood. Hasil ini bertolak belakang dengan penelitian terdahulu oleh Limbu et al. (2011), Lu et al. (2013), Ting et al. (2016) yang menyatakan bahwa ada hubungan positif antara privasi dengan loyalitas konsumen. Masalah privasi sebenarnya dapat diatasi dengan membangun kepercayaan melalui mekanisme seperti para perantara dan infrastruktur kelembagaan yang menetapkan dan menegakkan aturan serta peraturan (Benassi, 1999, dalam Agag et al., 2016). Berdasarkan pada penelitian sebelumnya oleh Caruana dan Ewing (2010), hubungan ini dapat dikarenakan sampel penelitian merupakan konsumen GrabFood yang sudah ada dan memang pengguna layanan GrabFood dalam kesehariannya sehingga konsumen ini kemungkinan sudah menerima bahwa GrabFood dapat diandalkan dan aman, karenanya tidak menimbulkan kekhawatiran lebih lanjut.

H3 menunjukkan bahwa ada hubungan positif antara kepuasan konsumen dan loyalitas konsumen terhadap layanan GrabFood. Hasil ini konsisten dengan penelitian terdahulu oleh Ariff et al. (2013), Lee dan Wong (2016), Sobihah et al. (2015), Ting et al. (2016), Yulisetiarini (2016), dan Limbu et al. (2011) yang menyatakan bahwa kepuasan konsumen memiliki pengaruh positif terhadap loyalitas konsumen. Menurut Ting et al. (2016), kepuasan konsumen merupakan anteseden langsung dari loyalitas konsumen e-commerce B2C. Berdasarkan Lee dan Wong (2016), semakin tinggi tingkat kepercayaan dan komitmen, maka konsumen akan semakin loyal atau setia. Adapun Agag (2019) juga menyatakan bahwa ketika konsumen berulang kali merasa puas dengan layanan yang ditawarkan oleh e-commerce, kepercayaan dan komitmen mereka terhadap perusahaan dapat meningkat. Kepuasan konsumen yang dipengaruhi oleh keamanan dan bukan pengelabuan memiliki hubungan yang paling kuat terhadap loyalitas konsumen. Dengan demikian, semakin tinggi kepuasan konsumen maka loyalitas konsumen untuk terus menggunakan layanan GrabFood juga meningkat karena konsumen yang puas akan menghargai produk yang ditawarkan oleh perusahaan (Román, 2010). 


\section{KESIMPULAN \& SARAN}

Perkembangan ekonomi digital di Indonesia yang semakin pesat dapat dilihat dari maraknya penggunaan mobile application. Salah satunya ialah penggunaan aplikasi seperti Grab. Grab yang pada awalnya merupakan aplikasi transportasi online, kemudian merambah ke bidang makanan dengan nama layanan GrabFood. GrabFood berfokus pada jasa pengiriman makanan yang diantarkan oleh pengemudi GrabBike. Akan tetapi, performa GrabFood bagi masyarakat Indonesia secara keseluruhan masih kalah dibandingkan Go-Food.

Penelitian mengenai loyalitas konsumen GrabFood dengan menggunakan variabel penelitian yang serupa masih belum banyak. Maka dari itu, penting untuk memahami apa yang menjadi faktor-faktor penyebab loyalitas konsumen GrabFood di kalangan mahasiswa Jabodetabek. Penelitian ini menganalisis hubungan antara keamanan, pemenuhan, bukan pengelabuan, serta privasi dengan kepuasan dan loyalitas konsumen. Dengan mengajukan 7 hipotesis, hanya 5 hipotesis yang didukung. Hubungan kepuasan konsumen GrabFood sangat kuat dengan loyalitas konsumen. Kepuasan konsumen dipengaruhi oleh faktor keamanan layanan GrabFood dan pemenuhan ekspektasi konsumen dalam menggunakan layanan GrabFood. Sedangkan, loyalitas konsumen juga dipengaruhi secara langsung oleh pemenuhan dan bukan pengelabuan atau kejujuran dari layanan GrabFood. Dengan demikian dapat disimpulkan bahwa GrabFood memiliki etika yang baik, dapat membangun hubungan yang baik dengan pelanggan sehingga memperoleh kepuasan dan kepercayaan pelanggan.

Dengan adanya penelitian ini, diharapkan kedepannya Grab dapat lebih memperhatikan faktor-faktor yang dapat mendorong kepuasan dan loyalitas konsumen, serta dapat meningkatkan performa dari GrabFood sendiri sehingga dapat bersaing secara maksimal dengan GoFood.

\section{REFERENSI}

Abbasi, A. S., Khalid, W., Azam, M., \& Riaz, A. (2010). Determinants of Customer Satisfaction in Hotel Industry of Pakistan. European Journal of Scientific Research, 48, 1, 97-105.

Agag, G. (2019). E-Commerce Ethics and Its Impact on Buyer Purchase Intentions and Loyalty: An Empirical Study of Small Medium Egyptian Businesses. Journal Business Ethics, 154, 389-410. doi:10.1007/s10551-017-3452-3

Agag, G., El-masry, A., Alharbi, N. S., \& Almamy, A. A. (2016). Development and Validation of an Instrument to Measure Online Retailing Ethics: Consumers' Perspective. Internet Research, 26, No. 5, 1158-1180. doi:10.1108/IntR-09-2015-0272

Agarwal, S., Singh, D., \& Thakur, P. (2013). Impact of Service Quality Dimensions Towards Customer Satisfaction in Indian Call Centers. Pacific Business Review International, 6(1), $2-14$.

Ahmad, D. M., \& Al-Zu'bi, D. A. (2011). E-banking Functionality and Outcomes of Customer Satisfaction: An Empirical Investigation. International Journal of Marketing Studies, 3, No. 1. doi:10.5539/ijms.v3n1050

Alvara Strategic Research. (2019). Perilaku dan Preferensi Konsumen Millennial Indonesia terhadap Aplikasi E-Commerce 2019. Online. Diambil kembali dari http://alvarastrategic.com/wp-content/uploads/2019/07/PRESS-CON-BAHASA-E-COMMERCEREPORT.pdf 
Antwi, S. K., \& Hamza, K. (2015). Qualitative and Quantitative Research Paradigms in Business Research: A Philosophical Reflection. European Journal of Business and Management, 7, No. 3, 223.

Ariff, M. S., Yun, L. O., Zakuan, N., \& Ismail, K. (2013). The Impacts of Service Quality and Customer Satisfaction on Customer Loyalty in Internet Banking. Procedia - Social and Behavioral Sciences, 81, 469-473. doi:10.1016/j.sbspro.2013.06.462

Bashir, A. A. (2015). A Research on Customer Adoption of e-Commerce in Nigeria. Proceedings of Sixteenth TheIIER International Conference, 141-145.

Bonett, D. G., \& Wright, T. A. (2014). Cronbach's Alpha Reliability: Interval Estimation, Hypothesis Testing, and Sample Size Planning. Journal of Organizational Behavior. doi:10.1002/job.1960

CNN Indonesia (2020). Grab Kuasai Pasar Ojol Indonesia, Grabfood Kalah dari Gofood. Retrieved June 17, from https:/www.cnnindonesia.com/teknologi/20190715190631-185412344/grab-kuasai-pasar-ojol-indonesia-grabfood-kalah-dari-gofood

Caruana, A., \& Ewing, M. T. (2010). How Corporate Reputation, Quality, and Value Influence Online Loyalty. Journal of Business Research, 63(9-10), 1103-1110. doi:10.1016/j.jbusres.2009.04.030

Chiu, J., Bool, N., \& Chiu, C. (2017). Challenges and Factors Influencing Initial Trust and Behavioral Intention to Use Mobile Banking Services in the Philippines. Asia Pacific Journal of Innovation and Entrepreneurship, 11, No. 2, 246-278. doi:10.1108/APJIE-082017-029

Chung, K. H., Yu, J. E., Choi, M. G., \& Shin, J. I. (2015). The Effects of CSR on Customer Satisfaction and Loyalty in China: The Moderating Role of Corporate Image. Journal of Economic, Business and Management, 3, No. 5, 542-547. doi:10.7763/JOEBM.2015.V3.243

Clifford, D., \& Lang, M. (2012). What Determines E-Loyalty? An Analysis of Factors Affecting On-Line Customer Retention. IADIS International Conference. Diambil kembali dari http://hdl.handle.net/10379/3416

Colak, M. (2016). The Impact of Environmental Uncertainty on International Joint Venture Performance: The Mediating Role of International Joint Venture Adaptation. J. Global Busines Advancement, 9, No. 3, 231-247. doi:10.1504/JGBA.2016.076721

Dubey, A., \& Srivastava, D. (2016). Impact of Service Quality on Customer Loyalty - A Study on Telecom Sector in India. IOSR Journal of Business and Management, 18(2), 45-55. doi:10.9790/487X-18214555

Elbeltagi, I., \& Agag, G. (2016). E-retailing Ethics and Its Impact on Customer Satisfaction and Repurchase Intention: A Cultural and Commitment-Trust Theory Perspective. Internet Research, 26(1), 288-310. doi:10.1108/IntR-10-2014-0244

Ganiyu, R. A., Uche, I. I., \& Elizabeth, A. O. (2012). Is Customer Satisfaction an Indicator of Customer Loyalty? Australian Journal of Business and Management Research, 2, No. 7, 1420.

Guo, X., Ling, K. C., \& Liu, M. (2012). Evaluating Factors Influencing Consumer Satisfaction towards Online Shopping in China. Asian Social Science, 8, No. 13. doi:10.5539/ass.v8n13p40 
Hamid, M. A., Sami, W., \& Sidek, M. M. (2017). Discriminant Validity Assessment: Use of Fornell \& Larcker Criterion Versus HTMT Criterion. Journal of Physics: Conference Series 890 012163, 890, 2. doi:10.1088/1742-6596/890/1/012163

Hila Ludin, I. H., \& Cheng, B. L. (2014). Factors Influencing Customer Satisfaction and ELoyalty: Online Shopping Environment among the Young Adults. Management Dynamics in the Knowledge Economy, 2, No. 3(6), 462-471.

Hoge, E. A., Bui, E., Goetter, E., Robinaugh, D. J., Ojserkis, R. A., Fresco, D. M., \& Simon, N. M. (2014). Change in Decentering Mediates Improvement in Anxiety in Mindfulness-Based Stress Reduction for Generalized Anxiety Disorder. Business Media New York, 228-235. doi:10.1007/s10608-014-9646-4

Hossain, M. (2019). Security Perception in The Adoption of Mobile Payment and The Moderating Effect of Gender. PSU Research Review, 3, No. 3, 179-190. doi:10.1108/PRR-03-2019-0006 Iqbal, S., \& Siddiqui, D. A. (2019). The Impact of Deceptive Advertising on Customer Loyalty: A Case of Telecommunication Industry in Karachi, Pakistan. 4. doi:10.5296/ijim.v4i1.14607

Ishak, A. (2012). Analisis Kepuasan Pelanggan Dalam Belanja Online: Sebuah Studi Tentang Penyebab (Antecedents) dan Konsekuensi (Consequence). Jurnal Siasat Bisnis, 16, No. 2, 141-154.

Jati, A.S. (2019). Kontribusi Grab ke Perekonomian Indonesia Tembus Rp 48,9 Triliun. https://inet.detik.com/cyberlife/d-4512920/kontribusi-grab-ke-perekonomian-indonesiatembus-rp-489-triliun

Javed, M. K., Hu, Z., Xu, J., \& Nadeem, A. H. (2014). The Impact of Consumer's Perceived Deception on Brand Trust, Brand Affect, and Brand Loyalty: Deceptive Tactics as an Impediment to Consumer Trust. Asian Journal of Business and Management, 2(6), 521-529.

Kara, H. (2019). Write a Questionnaire: Little Quick Fix. London, England: SAGE Publications Ltd.

Khumbar, V. M. (2011). Factors Affecting the Customer Satisfaction in e-Banking: Some Evidences Form Indian Banks. Management Research and Practice, 3(4), 1-14.

Krawcyzk, M. (2019). What Should be Regarded as Deception in Experimental Economics? Evidence from A Survey of Researchers and Subjects. Journal of Behavioral and Experimental Economics, 79, 110-118. doi:10.1016/j.socec.2019.01.008

Lee, W. O., \& Wong, L. S. (2016). Determinants of Mobile Commerce Customer Loyalty in Malaysia. Procedia - Social and Behaviornal Sciences, 224, 60-67. doi:10.1016/j.sbspro.2016.05.400

Limbu, Y. B., Wolf, M., \& Lunsford, D. L. (2011). Consumers' Perceptions of Online Ethics and Its Effects on Satisfaction and Loyalty. Journal of Research in Interactive Marketing, 5, No. 1, 71-89. doi:10.1108/17505931111121534

Lu, L.-C., Chang, H.-H., \& Yu, S.-T. (2013). Online Shoppers' Perceptions of E-Retailers' Ethics, Cultural Orientation, and Loyalty. Internet Research, 23, No. 1, 47-68. doi:10.1108/110662241311295773

Malik, A., Dhir, A., Kaur, P., \& Johri, A. (2020). Correlates of Social Media Fatigue and Academic Performance Decrement: A Large Cross-Sectional Study. Information Technology \& People. doi:10.1108/ITP-06-2019-0289 
Mertens, D. M. (2005). Research and Evaluation in Education and Psychology: Integrating Diversity with Quantitative, Qualitative, and Mixed Methods. California, United States of America: SAGE Publications, Inc.

Monferrer, D., Moliner, M., \& Estrada, M. (2019). Increasing Customer Loyalty Through Customer Engagement in the Retail Banking Industry. Spanish Journal of Marketing - ESIC, 23, No. 3, 461-484. doi:10.1108/SJME-07-2019-0042

Nassaji, H. (2015). Qualitative and Descriptive Research: Data Type Versus Data Analysis. Language Teaching Research, 19(2), 129-132. doi:10.1177/1362168815572747

Nawi, N., Al Mamun, A., Nasir, N., Abdullah, A., \& Mustapha, W. (2019). Brand Image and Consumer Satisfaction Towards Islamic Travel Packages: A Study on Tourism Entrepreneurship in Malaysia. Asia Pacific Journal of Innovation and Entrepreneurship, 13, No. 2, 188-202. doi:10.1108/APJIE-02-2019-0007

Padyab, A., \& Ståhlbröst, A. (2018). Exploring the Dimensions of Individual Privacy Concerns in Relation to the Internet of Things Use Situations. Digital Policy, Regulation and Governance, 20, No. 6, 528-544. doi:10.1108/DPRG-05-2018-0023

Pan, S., Giannikas, V., Han, Y., Grover-Silva, E., \& Qiao, B. (2017). Using Customer-Related Data to Enhance e-Grocery Home Delivery. Industrial Management \& Data Systems, 117, No. 9, 1917-1933. doi:10.1108/IMDS-10-2016-0432

Ringle, C. M., Wende, S., \& Becker, J. M. (2015). SmartPLS GmbH. Diambil kembali dari http://www.smartpls.com

Riquelme, I. P., Román, S., \& Iacobucci, D. (2016). Consumers' Perceptions of Online and Offline Retailer Deception: A Moderated Mediation Analysis. Journal of Interactive Marketing, 35, 16-26. doi:10.1016/j.intmar.2016.01.002

Roma'n, S. (2010). Relational Consequences of Perceived Deception in Online Shopping: The Moderating Roles of Type of Product, Consumer's Attitude Toward the Internet and Consumer's Demographics. Journal of Business Ethics, 95, 373-391. doi:10.1007/s10551010-0365-9

Rungtusanatham, M., Miller, J. W., \& Boyer, K. K. (2015). Theorizing, Testing, and Concluding for Mediation in SCM Research: Tutorial and Procedural Recommendations. Journal of Operations Management, 32(3), 99-113. doi:10.1016/j.jom.2014.01.002

Saleem, A., Ghafar, A., Ibrahim, M., Yousuf, M., \& Ahmed, N. (2015). Product Perceived Quality and Purchase Intention with Consumer Satisfaction. Global Journal of Management and Business Research: E Marketing Vol., 15(1).

Sarwar, M. Z., Abbasi, K. S., \& Pervaiz, S. (2012). The Effect of Customer Trust on Customer Loyalty and Customer Retention: A Moderating Role of Cause Related Marketing. Global Journal of Management and Business Research, 12(6).

Sekaran, U., \& Bougie, R. (2016). Research Methods for Business: A Skill-Building Approach. Chichester, West Sussex, United Kingdom: John Wiley \& Sons.

Semua Bermula Dari Sebuah Pertanyaan(n.d.). Retreived 2020, June 17, from https://www.grab.com/id/brand-story/

Shala, A., \& Balaj, D. (2016). Electronic Service Quality and Its Impact on Building Brand Loyalty in the Apparel e-Retailing Industry. Review of Innovation and Competitiveness(2), 5-30.

Sharma, G. (2017). Pros and Cons of Different Sampling Techniques. International Journal of Applied Research, 3(7), 749-752. 
Shenkoya, T., \& Dae-Woo, C. (2019). Impact of IoT on Social Innovation in Japan. Asia Pacific Journal of Innovation and Entrepreneurship, 13, No. 3, 341-353. doi:10.1108/APJIE-062019-0040

Singh, S. K. (2015). Advantages and Disadvantages of Probability Sampling Methods in Social Research. National Conference on Innovative Research in Chemical, Physical, Mathematical Sciences, Applied Statistics and Environmental Dynamics, 14-18.

Sobihah, M., Mohamad, M., Ali, N. A., \& Ismail, W. Z. (2015). E-Commerce Service Quality on Customer Satisfaction, Belief and Loyalty: A Proposal. Mediterranean Journal of Social Sciences, 6, No. 2. doi:10.5901/mjss.2015.v6n2p260

Song, H., Wang, J., \& Han, H. (2019). Effect of Image, Satisfaction, Trust, Love, and Respect on Loyalty Formation for Name-Brand Coffee Shops. International Journal of Hospitality Management, 79, 50-59. doi:10.1016/j.ijhm.2018.12.011

Taherdoost, H. (2017). Sampling Methods in Research Methodology: How to Choose a Sampling Technique for Research. International Journal of Academic Research in Management, 5, No. 2, 18-27. doi:10.2139/ssrn.3205035

Ting, O. S., Ariff, M. S., Zakuan, N., Sulaiman, Z., \& Saman, M. Z. (2016). E-Service Quality, ESatisfaction and E-Loyalty of Online Shoppers in Business to Consumer Market; Evidence form Malaysia. IOP Conf. Series: Materials Science and Engineering, 131. doi:10.1088/1757-899X/131/1/012012

Triki, A. (2019). Examining the Effect of Deception Detection Decision Aids on Investors' Perceptions of Disclosure Credibility and Willingness to Invest. International Journal of Accounting Information Systems, 33, 1-15. doi:10.1016/j.accinf.2019.03.003

Ursachi, G., Horodnic, I. A., \& Zait, A. (2015). How Reliable Are Measurement Scales? External Factors with Indirect Influence on Reliability Estimators. Procedia Economics and Finance, 679-686. doi:10.1016/S2212-5671(15)00123-9

Wahab, S., Zahari, A. S., Momani, K. A., \& Nor, N. A. (2011). The Influence of Perceived Privacy on Customer Loyalty in Mobile Phone Services: An Empirical Research in Jordan. International Journal of Computer Science Issues, 8, No. 2.

Yulisetiarini, D. (2016). The Effect of Relationship Marketing towards Customer Satisfaction and Customer Loyalty on Franchised Retails in East Java. Mediterranean Journal of Social Sciences, 7, No. 1. doi:10.5901/mjss.2016.v7n1p333 